\title{
ESTIMATION OF STRENGTH PARAMETERS OF AVIATION PRODUCTS MADE OF POLYMER COMPOSITES BASED ON MARKOV CHAIN THEORY
}

\author{
Rafal Chatys", Anna StefańSkA**, Krzysztof Piernik*, Konrad Stefański" \\ " Katedra Technik Komputerowych i Uzbrojenia, Wydział Mechatroniki i Budowy Maszyn, Politechnika \\ Świętokrzyska (Faculty of Mechatronics and Mechanical Engineering, Department of Applied Computer \\ Science and Armament Engineering, Kielce University of Technology), al.1000-lecia P.P. 7, 25-314 Kielce \\ ** Unaffiliated \\ chatys@tu.kielce.pl, stefanska.anna@poczta.fm, piernikkrzysztof@gmail.com,kstefanski@tu.kielce.pl
}

\begin{abstract}
The study investigates the fatigue strength of a component made of a glass composite material with polyester matrix, manufactured using a contact method (I) and by vacuum bagging (II). Modeling was carried out only for composite material II, due to significant spread of the strength of the composite material manufactured by contact lamination I, which means that such a material does not guarantee repeatability of the test results. Estimation of the composite material fatigue strength and residual strength was performed using a mathematical model based on the Markov chain theory. The model assumed that the material failure occurs at certain critical microvolume of the components operating within the plastic range. Observed relationships between the probability values and the distribution parameters for the static strength of the composite components, as well as the load values allow for deriving a fatigue curve equation. Obtained results are presented in the tables.
\end{abstract}

Keywords: composite material, composite testing, fatigue strength, residual strength, Markov's theory.

\section{INTRODUCTION}

Aviation industry, to a larger extent than other industries, needs numeric algorithms, information and analytical methods for modeling strength properties of fibrous composite materials (FCMs). Increased FCM production output [1, 2] and diversity goes along with increased use of such materials in technology, owed to progressing knowledge about their behavior under conditions equivalent to operational conditions $[3,4]$ or under modeling conditions (which typically simplify reality, e.g. to operational loads only). 
Description of the mechanical properties of the FCM components (fibers, fiber bundles or the composite material as a whole) is a complex process, which in most proposed models takes into account only initial stages of the structure complexity. In most cases, transfer from one structure to another (from fiber to fiber bundle and from fiber bundle to unidirectional composite) is associated with reduction of the material strength. The most general loading case for a component or structure involves randomly variable loads [5], which cause formation and development of fatigue damage within the material. The need to determine the fatigue life of units or components made of FCMs creates a necessity to search for increasingly accurate and efficient methods for service life evaluation, based on phenomenological hypotheses of fatigue damage cumulation. In most cases, verification of damage mechanisms and course of their cumulation is linked to the change trends of mechanical properties (residual strength, elastic, secant and dynamic modulus [6,7]) and variability of other physical quantities (e.g. acoustic signal) of investigated composite materials in the course of every performed fatigue cycle [8]. Calculations do not allow for determining, which of existing models is describing all values of material constants with proper accuracy, despite the fact that we may jointly apply the groups of hypotheses mentioned above (by combining them [9]). Therefore, experiments remain the only credible method for obtaining such data.

Except for phenomenological hypotheses, also statistical hypotheses are sometimes used. One of the methods for describing damage accumulation or summation of fatigue failures using static and fatigue properties of FCMs may involve Markov's networks [10, 11]. This is not a new idea though [12]. Presented modification [13, 14, 15] of the Markov's model (MM) uses new formulation of relationships between static and fatigue strength distribution parameters.

Thus far, the analysis of Markov's processes had been based on graphic representation of the reliability parameters of systems as function of time. Interesting mathematical models of the random processes are presented in the studies by Cullmann, Iosifescu [16], Fleming and Soner [17], Dynkin, Liggett or White [18]. Markov's networks, as one of the classes of stochastic processes, describing trajectory of discrete observations (when a parameter is continuous), is significantly relying on the theory of probability (e.g. finite Markov's chains). Research is based on a random combination of a random discrete time parameter, consisting of $n$ components in either suitable or non-suitable condition, with the possibility of converting into a state space. Determining conditions of Markov's chain may, but does not have to be linked to the condition description with a random variable. The main problem related to using Markov's chain is a major increase of number of states, and therefore also of the transitions and of the system components.

\section{MODEL OF FIBROUS COMPOSITE FAILURE}

\subsection{Theoretical assumptions for a failure of a fibrous polymer composite material}

Fatigue failure of a specimen occurs upon destruction of a certain critical microvolume (CMV) composed of longitudinal fibers or fiber bundles (operating within the plastic range) and plastic matrix (where the plastic deformations are accumulated during loading cycles. Thus, the CMV 
includes the matrix and other layers of fibers, with a laying angle different from the fibers operating along the loading direction).

The model assumes that components operate together (i.e. that within the plastic range, both fibers and the matrix work together, where $\varepsilon_{Y}$ stands for accumulation of irreversible plastic deformations). As a result of cyclic loading, number $r$ of components in CMV operating in the plastic range (able to take the stress) is reduced by $r_{R}$, causing destruction of components working along the fibers, until the specimen eventually fails.

Model of fatigue strength accumulation has been described with a probability transition matrix, where all probabilities below the diagonal are zero. Additional simplifications have been introduced into the model, taking into account passage (on the first level, in relation to the existing absolute state) through a simple Markov's chain, and appropriately simple model of damage accumulation. This problem has been addressed and discussed in many studies $[8,19]$, which dealt with application of phenomenological models for modeling of the FCM fatigue processes. Selected probabilities in the proposed model may create conditional probabilities. The probability transition matrix may be expressed as follows:

$$
P=\left[\begin{array}{ccccccc}
q_{1} & p_{1} & 0 & & & \ldots & 0 \\
0 & q_{2} & p_{2} & 0 & & \ldots & 0 \\
0 & 0 & q_{3} & p_{3} & 0 & \ldots & 0 \\
\ldots & \ldots & \ldots & \ldots & \ldots & \ldots & \ldots \\
0 & & & \ldots & q_{r} & p_{r} & 0 \\
0 & & & \ldots & 0 & 0 & 1
\end{array}\right]
$$

where: $q_{i}=1-p_{i}, i=1, \ldots, r$

In the analyzed Markov's chain, there are $r$ irreversible states and one absorbing state, and $r$ irreversible states are treated as $r$ cases of damage, of which accumulation leads to failure of certain critical microvolume and achieving the absorbing state. The main characteristics of such a Markov's chain, where it is only a transition to the next state is possible, are well known. Fatigue strength (time until absorption) takes a following form:

$$
T=X_{1}+X_{2}+\ldots+X_{r}
$$

where: $X_{i}, i=1 ; r$-time during which the process remains (is) in $i$-th state.

Random variable $X_{i}$ has a geometric distribution:

$$
P\left(X_{i}=n\right)=\left(1-p_{i}\right)^{n-1} p_{i}
$$

Expected value:

$$
E\left(X_{i}\right)=1 / p_{i}
$$

Dispersion:

$$
V\left(X_{i}\right)=\left(1-p_{i}\right) / p_{i}^{2}
$$


Then, for the random variable $T$ :

$$
E(T)=\sum_{i=1}^{r} 1 / p_{i} \quad, V(T)=\sum_{i=1}^{r}\left(1-p_{i}\right) / p_{i}^{2}
$$

Function generating probabilities for the random variable $T$ (inverse transformation, which yields the distribution of probability for the random variable $T$ ) may be expressed as:

$$
G_{T}(z)=\sum_{i=0}^{\infty} p_{T}(i) \cdot z^{i} \prod_{i=1}^{\infty} \frac{z p_{i}}{1-z\left(1-p_{i}\right)}
$$

Cumulative distribution function

$$
F_{T}(t)=p_{1 r+1}(t), \mathrm{t}=1,2,3
$$

where: $p_{1 r+1}(t)$ is $(1, r+1)$ - matrix component.

$$
P(t)=P^{t}
$$

may be expressed as:

$$
F_{T}(t)=a P^{t} b
$$

where: $a=(100 \ldots 0) ; b=(00 \ldots 01)^{\mathrm{T}}-$ column vector.

It needs to be taken into account that the product of matrix $P^{i}$ and vector $b$ is a column vector of the fatigue strength distribution function, of which components correspond to the initial states of the Markov's chain: $\left(F_{T}^{(1)}(t) \cdot F_{T}^{(2)}(t), \ldots . F_{T}^{(r)}(t)\right)$. In general case, it may be applied for determining the distribution function of the fatigue strength at certain assumed probability distribution under initial conditions $\pi$. If $\pi$ is known, then the fatigue strength distribution function is described with the formula:

$$
F_{T}(t)=\pi P^{t} b
$$

Possibility of taking into account the distribution of probabilities under initial conditions $\pi$ needs to be considered as a potential reserve, which may be utilized for specific composite structures (magnitude of reinforcement work) or for taking into account the impact of composite material forming technology. The model was designed for minimum amount of parameters, and assumes $\pi=\mathrm{a}$.

In the application for the considered task, the problem involves identification of relationships between the probabilities $p_{i}, \mathrm{i}=1, \ldots, r$, and the distribution parameters for the static strength of the FCM components, as well as magnitude of loads, in the form which would allow deriving the equation of the fatigue curve. It has been assumed that 1 step of the Markov's chain (one or 1000 cycles possible) causes failure of no more than one component (e.g. one fiber bundle). If there are other $(R-i)$ parallel components working, featuring the same distribution function and static strength $\mathrm{F}(\mathrm{s})$, then the probability of the next failure (within the remaining components) is equal to:

$$
p_{i}=1-\left(1-F\left(s_{i}\right)\right)^{R-i}
$$

where: $R$ - initial number of components; $i$ - number of failed components; $s_{i}-$ stress (loading of a single component) corresponding to a uniform load distribution among remaining $(R-i)$ components. 
It has been assumed, that in general case:

$$
s_{i}=\frac{S R=i S_{f}}{R-i}=\frac{S\left(1-i S_{f} / R S\right)}{1-i / R}
$$

where: $\mathrm{S}$ - initial (at the first step of the process) load in each component; $\mathrm{S}_{f}$ - average stress, at which a component is still able to carry the load (at least at the initial phase of the working FCM components - accumulation of component damage, which occurs at different cross-sections).

If all the parameters of the model are known (formulas 5,7,9), then it is possible to calculate the fatigue curve. Assuming that a single step of the Markov's chain corresponds to $\mathrm{k}_{\mathrm{M}}$ of cycles, we apply a modified formula:

$$
E(T)=k_{M} \sum_{i=1}^{r} 1 / p_{i}, V(T)=k_{M}^{2} \sum_{i=1}^{r}\left(1-p_{i}\right) / p_{i}^{2}
$$

This study assumes a log-normal distribution of strength:

$$
F(s)=\Phi\left(\left(g(s)-\theta_{0}\right) / \theta_{1}\right)
$$

where: $\Phi($.$) is a function of a standard normal distribution, g(\mathrm{~s})=\log (\mathrm{s})$

In general case, the model under consideration determines constant $\eta=\left(\theta_{0}, \theta_{r}, r, R, k_{M^{p}} S\right)$ with six components: $\theta_{0}, \theta_{1}$ - distribution parameters of the static strength of the composite components (expected value and standard deviation of the strength logarithm); $R$ - number of components within the composite material's "critical volume", of which destruction is tantamount to total failure of the specimen; $r$ - critical number of components within CMV (value $r$ has a significant impact on the dissipation and the variation coefficient of the fatigue strength); $\rho=r / R$ ratio approximates the failure value (failure share) in the specimen cross-section, corresponding to the specimen's total failure; $k_{M}$-number of cycles corresponding to a single step of the Markov's chain; $S_{f}$ - residual strength of already failed (in other cross-sections) components (this value depends on the number of layers, their orientation and the matrix properties).

\section{SELECTED MATERIAL AND TESTING METHODOLOGY}

\subsection{Material selected for testing}

The subject of testing was an FCM formed with the contact method (composite I) and a composite material formed by injecting resin (by sucking it in) into a mold (i.e. vacuum bagging - composite II) The composite material was reinforced with a $600 \mathrm{~g} / \mathrm{m}^{2}$ fiberglass mat with a polyester matrix (Firestop@8170-W1).

Methods involving pressurized resin injection into the mold, one of which is the vacuum bagging technology, combines features of manual lamination (i.e. lamination of reinforcement over the previously prepared molds) with those of pressure forming (pressing all laminated layers together by created negative pressure for the duration of their hardening). Forming stages for the composite material II by vacuum bagging method and process parameters of laminates formed at the Composite Facility of "BELLA" company are shown in Figure 1 and Table 1 respectively. 
a)
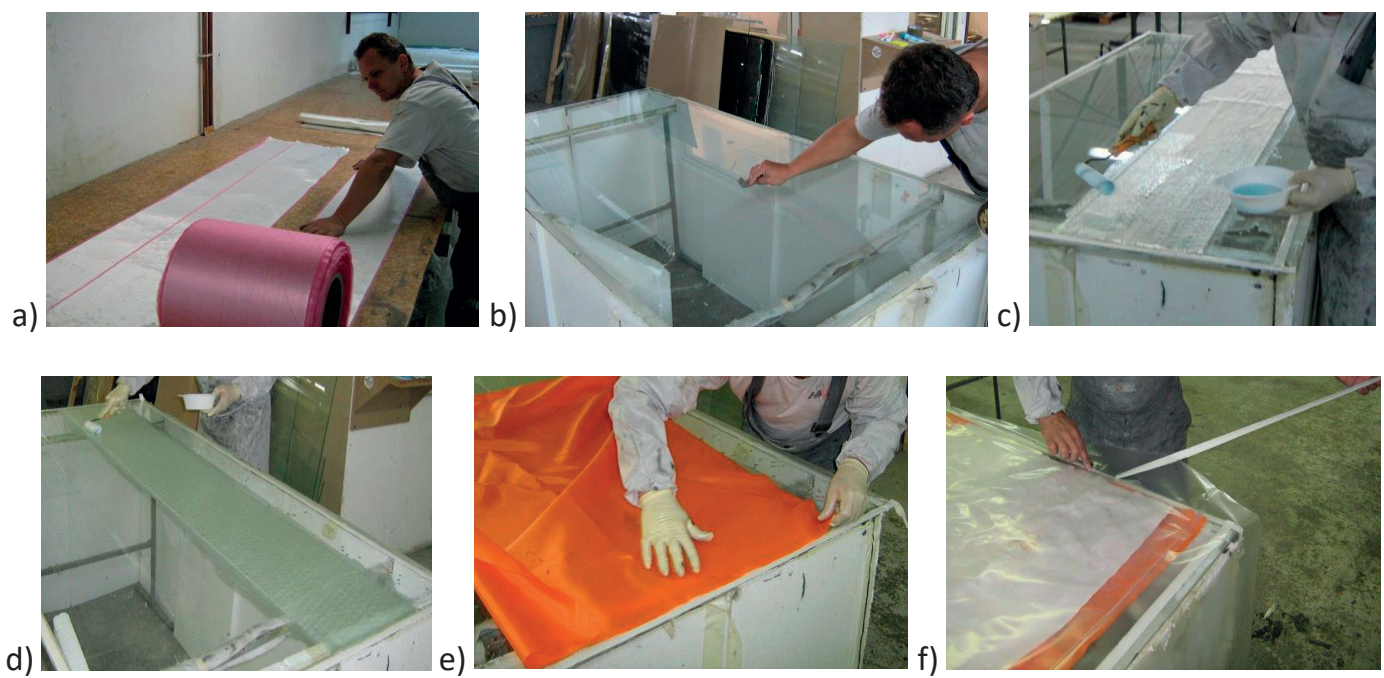

Fig. 1. Forming stages of the composite material II made by vacuum bagging: a - cutting out and preparing the reinforcement; $\mathrm{b}$-mold surface preparation; $\mathrm{c}$-soaking individual laminated reinforcement layers with resin; $\mathrm{d}$ - ready composite material II; e - application of auxiliary layers under the film, such as peel ply, breathing material; $f$-application of a double-sided sealing tape made of special bonded film around the edge of the mold, under which the components of the composite material (and auxiliary material) had been present [Chatys, 2015]

Table 1. Summary of the results of the analyzed compression tests of the composite material specimens

\begin{tabular}{|c|c|c|c|c|}
\hline Composite & Hardener, $\%$ & $\begin{array}{c}\text { Demolding time, } \\
\mathrm{h}\end{array}$ & $\begin{array}{c}\text { Gelation time, } \\
\mathrm{h}\end{array}$ & Additional heating \\
\hline I & $\begin{array}{c}\text { Butanox M50, } 4 \\
\text { with NCL-10,2 initiator }\end{array}$ & 24 & 1 & $30^{\circ} \mathrm{C}(16 \mathrm{~h})$ \\
\cline { 1 - 3 } II & & $\left(T=22-23^{\circ} \mathrm{C}\right)$ & \\
\hline
\end{tabular}

[Chatys, Piernik, 2015]

Measurements of the shape and weight of the specimens cut on a numerically-controlled CNC machine were performed in line with DIN-EN ISO 527 standard. In order to neutralize the impact of stress concentration at the point of fixing in the machine on the mechanical properties of the polyester composite and to protect it from surface failure, overlays were applied on the specimens (thus increasing the area of the uniform stress distribution within the tested specimen). Following designations of the specimens subjected to the tensile testing were used:

- Composite material I. 'A_(1, 2, 3) - xxx': where, 'A' stands for a polyester composite in arrangement $[0 / 90]_{\mathrm{S}}$ with measurement base $L_{B P}=150 \mathrm{~mm}$ with loads along directions: $0^{\circ}(1), 45^{\circ}(2), 90^{\circ}(3)$ in relation to the reinforcement with a specimen number ' $x x x$ '), made using the contact method;

- Composite material II. ' $\mathrm{P}(1,2,3)-\mathrm{xxx}_{\text {- }}$ ' where, ' $\mathrm{P}$ ' stands for a polyester composite in arrangement $[0 / 90]_{\mathrm{S}}$ with a measurement base $L_{B P}=150 \mathrm{~mm}$ with loads along directions: $0^{\circ}$ $(1), 45^{\circ}(2), 90^{\circ}(3)$ in relation to the reinforcement with a specimen number ' $x x x$ ', made using the vacuum bagging method. 


\subsection{Methodology. Statistical and fatigue testing}

The tensile test of the composite material specimens was performed using the INSTRON machine equipped with a Flex Test SE measurement instrument and an MTS controller [20]. Loads were measured using strain rosettes HBM 1-XY91-6/350, consisting of two perpendicular strain gage sensors and individual gages HBM 1-XY91-6/350 with identical measurement lengths of $6 \mathrm{~mm}$ and nominal resistance of $350 \Omega$.

Rosettes and single extensometers were placed at the opposite sides of the specimen. Measurements made with the extensometers, loads and displacements were recorded using HBM Spider 8 with "Catman" controller. Tests were performed at the head movement rate of $1.5 \mathrm{~mm} / \mathrm{min}$. The axial stress was determined as a ratio of the strength and the measured average cross-section of the tested specimens. Poisson's ratio $\left(v_{x y}\right)$, was determined from a transverse strain - axial strain curve. Finding the average value of static strength $\left(\mathrm{S}_{\text {stati. }}\right)$ of a polymer composite material as a result of the tensile test was used to determine S-N fatigue dependency.

Due to the fact that some structures operate under large loads but low number of cycles, it had been decided that the testing would be carried out with a maximum number of cycles (up to 55,000) with a predetermined force. Specimens of polyester-based composites were subjected to cyclic loading at 3 levels $K^{*} S_{\text {statist }}(K=0.3 ; 0.4 ; 0.5)$, at assumed frequency $f=6 \mathrm{~Hz}$. Conducted experiments allowed for determining the fatigue curves for polymer materials $(\mathrm{S}-\mathrm{N})$, which were subsequently used to determine the residual strength load levels $\left(S_{R}\right)$ at certain number of cycles.

\section{ANALYSIS OF THE OBTAINED RESULTS}

Results obtained from the tensile test of FCMs manufactured using the manual lamination method show considerable scatter of mechanical properties, when compared to a material made using the vacuum bagging method (Table 2), due to defects, which occurred during forming (or because of errors in the manufacturing process or other secondary operations). The defects caused local stress concentrations and cracking of components (adjacent fibers) until failure of the laminate.

Increasing the angle from $0 \div 90^{\circ}$ caused increase of the composite's strength. The highest strength of $174.6 \mathrm{MPa}$ has been obtained for the composite material II cut at the angle of $90^{\circ}$ from the reinforcement, formed using the vacuum bagging method (the principle was the same for the FCM made using the manual method - composite material I).

Accumulation of defects and failures (microslots, microcracks of the composites or voids in the polyester matrix) in the produced structures are presented in Figure 2. Failures listed in the results of testing may have varying impact on the degradation and destruction of the composite structure for different loading angles (like we observed for the sample cut at the angle of $45^{\circ}$ from the reference system - Table 3). 


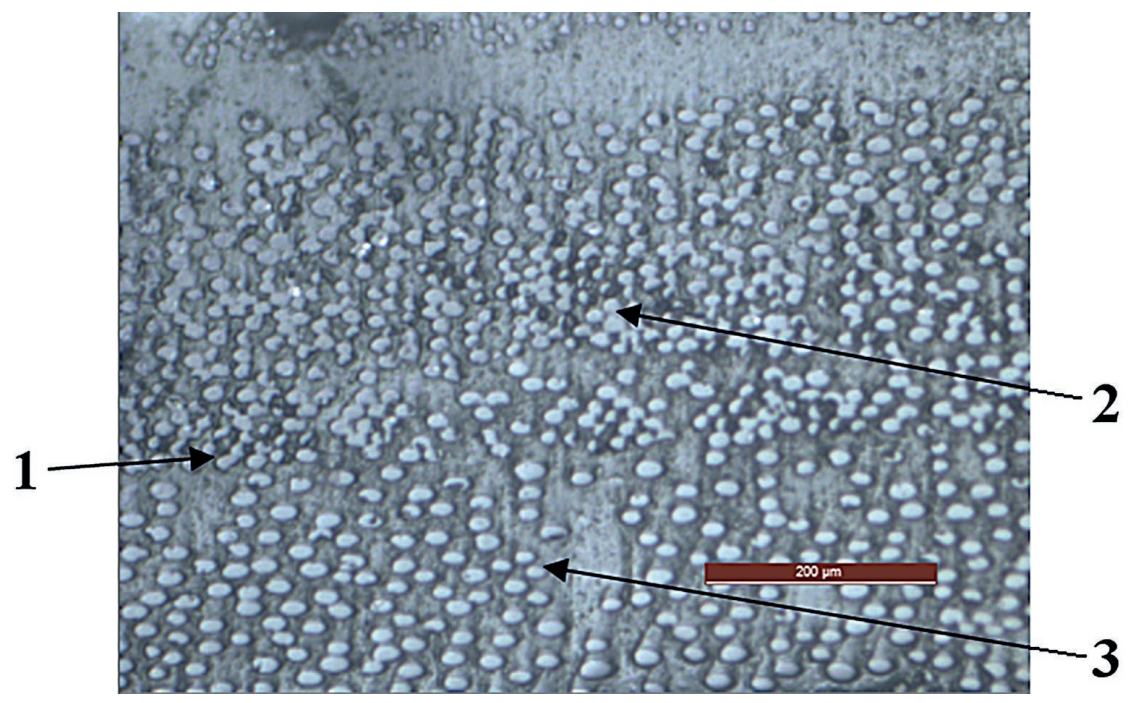

Fig. 2. Defects in the microstructure: 1 - microslots; 2 - microcracks of the components; 3 - voids in the polyester matrix [Chatys, Piernik, 2015]

Loss of adhesion at the fiber-matrix boundary (the so-called debonding) is a microstructural failure, which occurs at the earliest, initial stages of the polymer composite degradation. At this stage of material destruction, adhesive cracks do not exert large influence on the macroscopic properties of the material yet, but they usually are the first link of a chain leading to the material failure. Boundary layer failure occurs due to exceeding the critical stress values, i.e. stresses normal to the side surface of the fiber, and tangential (causing shearing of the boundary between the fiber and the matrix).

This knowledge was subsequently used to estimate the strength of the composite material of a symmetrical structure, with the polyester matrix.

Table 2. Summary of the results of the analyzed tensile test of the composite material specimens [Chatys, Piernik, 2015]

\begin{tabular}{|c|c|c|c|}
\hline \multicolumn{4}{|c|}{ Average strength of the glass composite material with the polymer matrix } \\
\hline Properties/ angle (symbols) & $0^{0}\left(\mathrm{~A} 1-^{\prime} \mathrm{xxx}\right.$ ') & $45^{0}\left(\mathrm{~A} 2-^{6} \mathrm{xXX} \mathrm{x}^{\prime}\right)$ & $90^{0}($ A_3-'xxx') \\
\hline \multicolumn{4}{|c|}{ Composite made using the manual method } \\
\hline$S, \mathrm{MPa}$ & 117,57 & 58.23 & 122.94 \\
\hline Scatter $S, \mathrm{MPa}$ & $109.30-127.40$ & $24.03-69.95$ & $89.30-154.60$ \\
\hline$E, \mathrm{GPa}$ & 9,70 & 9.50 & 11.30 \\
\hline Scatter $E, \mathrm{GPa}$ & $9.49-9.82$ & $9.20-9.92$ & $10.33-12.03$ \\
\hline \multicolumn{4}{|c|}{ Composite made using the vacuum bagging method } \\
\hline Properties/ angle (symbols) & $0^{\circ}\left(\mathrm{P} \_11^{\circ} \mathrm{xxx}\right)$ & $45^{\circ}\left(\mathrm{P} 2-{ }^{\prime} \mathrm{xxx} x^{\prime}\right)$ & $90^{\circ}\left(\mathrm{P} \_3-^{-} \mathrm{xxx}\right)$ \\
\hline$S, \mathrm{MPa}$ & 126.71 & 73.67 & 174.60 \\
\hline Scatter $S, \mathrm{MPa}$ & $115.70-169.00$ & $67.41-78.17$ & $160.20-196.70$ \\
\hline$E, \mathrm{GPa}$ & 11.27 & 9.26 & 14.18 \\
\hline Scatter $E, \mathrm{GPa}$ & $10.13-12.23$ & $8.73-10.21$ & $12.96-15.81$ \\
\hline
\end{tabular}


Table 3. Summary of the results for the FCM cut at the angle of $45^{\circ}$ from the reference system [Chatys, Piernik, 2015]

\begin{tabular}{|c|c|c|c|}
\hline \multicolumn{4}{|c|}{$\mathrm{FCM}$ cut at the angle of $45^{\circ}$ from the reference system } \\
\hline Specimen designation & $F_{\max }, \mathrm{kN}$ & $\sigma_{\max }, \mathrm{MPa}$ & $E, \mathrm{GPa}$ \\
\hline \multicolumn{4}{|c|}{ Composite made using the manual method } \\
\hline A_2-01 & 5.485 & 69.95 & 9.92 \\
\hline A_2-02 & 5.367 & 68.72 & 9.42 \\
\hline A_2-03 & 4.632 & 59.30 & 9.76 \\
\hline A_2-04 & 5.400 & 69.14 & 9.20 \\
\hline A_2-05 & 2.014 & 24.03 & 9.27 \\
\hline Average value & $\mathbf{4 . 5 7 9 6}$ & $\mathbf{5 8 . 2 3}$ & $\mathbf{9 . 5 0}$ \\
\hline \multicolumn{3}{|c|}{ Composite made using the vacuum bagging method } \\
\hline P_2-01 & 4.246 & 67.41 & 8.73 \\
\hline P_2-02 & 4.612 & 75.14 & 8.96 \\
\hline P_2-03 & 4.232 & 76.36 & 9.65 \\
\hline P_2-04 & 4.344 & 71.25 & 8.76 \\
\hline P_2-05 & 4.350 & 78.17 & 10.21 \\
\hline Average value & $\mathbf{4 . 3 5 7}$ & $\mathbf{7 3 . 6 7}$ & $\mathbf{9 . 2 6}$ \\
\hline
\end{tabular}

\section{MODELING OF THE STRENGTH PARAMETERS FOR THE COMPOSITE MATERIAL II}

Estimation of the fatigue average $E(T(S))$ at any value of $S$, subsequently may lead to quite accurate determination of the fatigue curve [6]. The results of the tests presented in the Fig. 3 illustrate match between the data of the fatigue curve (T-N) and the experiment results (taking into account the number of initial loads at three stress levels $K^{*} S_{\text {statist }}\left(\mathrm{K}_{0.1}=0.3 ; 0.4 ; 0.5\right)$.

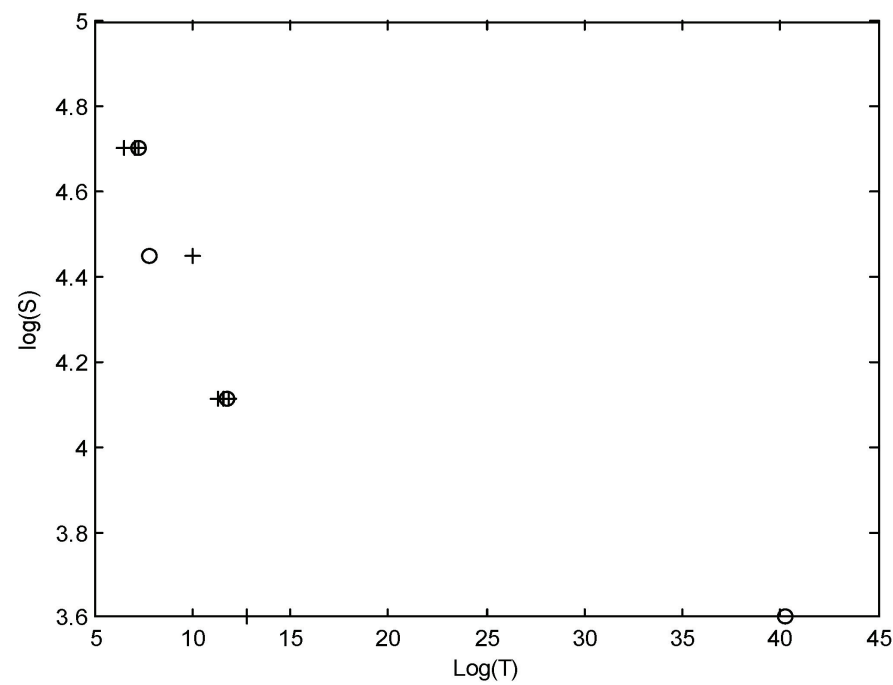

Fig. 3. Average fatigue strength data for the composite material II formed using the vacuum bagging method obtained by experiment $(+)$ and modeling (o) for three loading $\operatorname{cases}\left(S_{l}, n_{1}\right)=(52.38 \mathrm{MPa} 55,000$; 69.84 MPa, 30,000; 87.30 MPa, 10,000) [Chatys, Stefański, 2016] 
Analyzed data for the composite material II, which was subsequently used to model the parameters of the model (for the skewness $R=0.1$ ) are presented in Table 4. No significant influence of the dependency between the residual strength and the number of cycles has been found. Value changes of 8 to $10 \%$ in relation to the average stresses at set number of cycles have been observed (Table 5).

For selected model parameters, at lower stress values, after certain number of load cycles $\left(\left(S_{l}, n_{l}\right)=52.38 \mathrm{MPa}, 55,000\right)$, insignificant over-increase may be observed, and at high values $\left(\left(S_{3}, n_{3}\right)=87.30 \mathrm{MPa}, 10,000\right)$ - there is a insignificant lowering of the "forecasted" residual strength compared to the value obtained by experiment. It is still necessary to determine dependence of this effect on the duration of cyclic loading (number of cycles). For this purpose, it was assumed that the number of the loading cycles of quite high values is approximately equal to the minimum fatigue strength for the specified level of loading obtained experimentally. It needs to be emphasized that the experimental data obtained for three loading levels lie within the $p$-quantile confidence level (for $90 \%$ ).

Table 4. Parameters of the assumed model for the composite material II [Chatys, Stefański, Stefańska, 2016]

\begin{tabular}{|l|c|}
\hline \multicolumn{1}{|c|}{ Parameters } & Parameter values \\
\hline Average strength value for the longitudinal components, $L_{R}{ }^{*}$ & 5.1625 \\
\hline$R=\exp \left(L_{R}\right), \mathrm{MPa}$ & 174.60 \\
\hline $\begin{array}{l}\text { Average standard deviation }\left(S t d_{R P}\right) \text { of the longitudinal component strength in the } \\
\text { logarithmic scale }\end{array}$ & 0.1 \\
\hline Number of the longitudinal components in the critical microvolume $\left(r_{R P}\right)$ & 4 \\
\hline $\begin{array}{l}\text { Relative value of the surface area of the working longitudinal components in the } \\
\text { FCM }\left(f_{R O}\right)\end{array}$ & 0.65 \\
\hline Number of the cycles equivalent to one step of the Markov's chain $\left(k_{m}\right)$ & 2865 \\
\hline
\end{tabular}

*calculations in a natural logarithm

Table 5. Modeled values of the residual strength of the composite material II [Stefańska, 2016]

\begin{tabular}{|l|c|c|c|}
\hline \multicolumn{4}{|c|}{ at skewness $R=0.1$} \\
\hline No. & Loads $(K), \mathrm{MPa}$ & $\begin{array}{c}\text { Average } S_{R}, \\
\mathrm{MPa}\end{array}$ & Modeled $S_{R}, \mathrm{MPa}$ \\
\hline 1 & 52.38 & 147.03 & 165.80 \\
\hline 2 & 69.84 & 132.31 & 134.13 \\
\hline 3 & 89.70 & 130.76 & 120.76 \\
\hline
\end{tabular}

\section{CONCLUSIONS}

The analysis of modeling the strength properties of the composite material II manufactured using the vacuum bagging method based on a stationary Markov's chain at skewness $R=0.1$ is quite accurately reflecting the "lower part" of the fatigue curve (at 10,000 loading cycles - Fig. 3) and the average residual strength values (Table 5). The model along with the analysis of the statistical parameters may be used as a tool for "forecasting" the S-N curve and the residual 
strength distribution function after preliminary fatigue loading. It has also been determined that there is a considerable scatter of the strength parameters of the composite material I formed using the contact method (specimen A_2-05 in comparison to other specimens or to the average strength of the composite material I - Table 3), which proves that the contact lamination method does not guarantee the repeatability of results, and therefore, modeling was performed only for the composite material II formed using the vacuum bagging method.

\section{REFERENCES}

[1] Lifshitz, J. M., 1988, „Compressive Fatique and Static Properties of a Unidirectional Graphite/ Epoxy Composite" Journal of Composites Technology and Research, 10 (3), pp. 100-106.

[2] Chatys, R., Darska, J. and Opala, M., 2005, "The Effect of the Technological Parameters on the Quality of Composite Materials Produced with the RTM Method.”, International Conference "Terotechnology'2005”, Kielce, September 28-30, 2005., "Mechanika”, nr. 83, pp. 21-28.

[3] Chatys, R., 2009, „Mechanical Properties of Polymer Composites Produced by Resin Injection Molding for Applications Under Increased Demands for Quality and Repeatability”, Journal Ultrasound, 64(2), pp. 35-38.

[4] Topoliński, T. and Weiner, W., 1995, „Programowane badania zmęczeniowe ogniw przenośnika na tle wyników badań eksploatacyjnych" (Programmable the study fatigue the conveyor links on the background of the results of operational research - available in Polish), VI Konferencja nt. „Nowe kierunki modyfikacji i zastosowań tworzyw sztucznych” (6th Conference on "New directions of modifications and uses of plastics"), Poznań, 10-13.05.1995 pp. 137-142.

[5] Szala, J., 2007, „Podstawowe problemy konstruowania złożonych obiektów ze względu na zmęczeniowe pękanie" (Basic problems of constructing complex objects due to fatigue cracking - available in Polish), XXIII Sympozjon Podstaw Konstrukcji Maszyn (23rd Symposium on Machine Design Basics), Przemyśl, 17-21 September 2007, Ed. by PRz, Rzeszów.

[6] Reifsnider, K. L. and Stinchcomb, W. W., 2005, A Critical-Element Model of the Residual Strength and Life of Fatigue-Loaded Composite Coupons", Composite Materials: Fatigue and Fracture, ASTM STP 907. pp. 298-313.

[7] Yang, J. N., Jones, S. L., Yang, S. H. and Meskini, A., 1990, „A Stiffness Degradation Model for Graphite/Epoxy Laminates", J, of Composites Materials, 24(3), pp. 753-763.

[8] Broutman, L. J. and Sahu, S., 1972, „A New Theory to Predict Cumulative Fatigue Damage in Fiberglass Reinforced Plastics”, Composite Materials: Testing and Design, 2nd Conference American Society for Testing and Materials, Philadelphia, ASTM STP, 497, pp. 170-188.

[9] Rotem, A., 1986, „Fatigue and Residual Strength of Composite Laminates”, Engineering Fracture Mechanics, 25(6), pp. 819-827.

[10] Paramonov, Yu. M., Kleinhof, M. A. and Paramonova, A. Yu., 2006,"Markov Model of Connection Between the Distribution of Static Strength and Fatigue Life of a Fibrous Composite", Mechanics of Composite Materials, 42(5), pp. 615-630.

[11] Paramonov, Yu. and Andersons, J., 2007, „A family of weakest link models for fibre strength distribution", Composites: Part A38, pp. 1227-1233. 
[12] Kemeny, J. G and Snell, J. L., 1966, „, Finite Marcov Chains”, Princeton: N.J. Van Nostrand.

[13] Chatys, R., Paramonova, A. Yu. and Kleinhofs, M. A., 2011, „Analysis of Residual Strength after Fatigue in Fibrous Composite using Markov Chains Model", Monography: "Selected Problems of Modeling and Control in Mechanics", Edited by Stanisław Adamczak and Leszek Radziszewski, Kielce, 2011, pp. 166-178.

[14] Paramonov, J., Chatys, R., Anderson, J. and Kleinhofs, M., 2012, „Markov Model of Fatigue of a Composite Material with Poisson Process of Defect Initiation", Mechanics of Composite Materials, .48(2), pp. 211-228.

[15] Paramonov, Yu., Chatys, R., Andersons, J. and Kleinhofs, M., 2011, „Poisson process of defect initiation in fatigue of a composite material”, International Conferences „RelStat'2011”, 20-21.10.2011, Riga Latvia, pp. 1-12 (CD).

[16] Iosifescu, M., 1988, „Skończone procesy Markowa i ich zastosowanie” (Finished Markov processes and their application - available in Polish), Ed. by PWN, Warsaw, Poland.

[17] Fleming, W. H. and Soner, H. M., 1993, „Controlled Markov processes and viscosity solutions” Springer Verlag, New York.

[18] White, D. J., 1992,"Markov decision processes", Chichester: John Wiley.

[19] Found, M. S and Quaresimin, M., 2003, „Two-stage fatigue loading of woven carbon fiber reinforced laminates", Fatigue Fract. Eng. Mater. Struct. 26, pp. 17-26.

[20] ASTM D638 - Standard Test Method for Tensile Properties of Plastics.

\section{SZACOWANIE PARAMETRÓW WYTRZYMALOŚCIOWYCH WYROBÓW LOTNICZYCH Z KOMPOZYTÓW POLIMEROWYCH Z UWZGLĘDNIENIEM TEORII LAŃCUCHÓW MARKOWA}

\section{Streszczenie}

W pracy zbadano wytrzymałość zmęczeniową kompozytu szklanego o osnowie poliestrowej, wytworzonego metodą kontaktową (I) i metodą worka próżniowego (II). Modelowanie przeprowadzono tylko dla kompozytu II, ze względu na znaczny rozrzut wytrzymałości kompozytu wykonanego metodą laminowania kontaktowego I, co oznacza kompozyt ten nie daje gwarancji powtarzalności wyników badania. Do szacowania wytrzymałości zmęczeniowej i wytrzymałości resztkowej kompozytów zastosowano model matematyczny bazujący na teorii łańcuchów Markowa. W modelu założono, iż zniszczenie materiału zachodzi przy pewnej krytycznej mikroobjętości komponentów pracujących w zakresie sprężystym. Zaobserwowane związki prawdopodobieństw z parametrami rozkładu wytrzymałości statycznej komponentów kompozytów i wielkości obciążeń pozwalają otrzymać równanie krzywej zmęczeniowej. Uzyskane wyniki badań zestawiono w tabelach.

Słowa kluczowe: kompozyt, badania kompozytów, wytrzymałość zmęczeniowa, wytrzymałość resztkowa, teoria Markowa. 